УДК 623.618 .5

${ }^{1}$ Денис Михайлович Запара

${ }^{1}$ Михайло Борисович Бровко

${ }^{1}$ Сергій Анатолійович Бортновський (канд. техн. наук, доцент)

${ }^{2}$ Павло Вікторович Опенько (канд. техн. наук)

${ }^{1}$ Харківський національний університет Повітряних Сил імені Івана Кожседуба, Харків, Украӥна

${ }^{2}$ Національний університет оборони Украйни імені Івана Черняховського, Київ, Украӥна

\title{
ФОРМАЛІЗАЦІЯ ПРОЦЕДУРИ ПРОГНОЗУВАННЯ ПОШКОДЖЕНЬ ОЗБРОЄННЯ ТА ВІЙСЬКОВОЇ ТЕХНІКИ ЗЕНІТНИХ РАКЕТНИХ ВІЙСЬК В ПЕРСПЕКТИВНІЙ АВТОМАТИЗОВАНІЙ СИСТЕМІ УПРАВЛІННЯ МАТЕРІАЛЬНО-ТЕХНІЧНИМ ЗАБЕЗПЕЧЕННЯМ
}

В статті розглядаються питання удосконалення інформаційного забезпечення перспективноі автоматизованої системи управління матеріально-технічним забезпеченням иляхом формування процедури прогнозування очікуваних почкоджень зразків озброєння та військової техніки (OBT) зенітних ракетних військ (ЗРВ) безпосередньо від впливу фугасної дї засобу ураження. Якісним показником прогнозування рівня пошкоджень зразка ОВТ ЗРВ обрана ознака ступеню його пошкоджень, в якості критерія визначення ступеню пошкоджень зразка ОВТ ЗРВ від впливу фугасної дії засобів ураження обрана кількість засобів ураження, які влучили. Проведений розрахунок імовірності отримання пошкоджень структурним елементом зразка ОВТ ЗРВ від фугасної дії засобів ураження з урахуванням інженерного обладнання позицій.

Ключові слова: матеріально-технічне забезпечення, засоби ураження, зразок озброєння та військової техніки, пошкодження, структурний елемент, фугасна дія, площчинне ураження, прицільне ураження.

\section{Вступ}

Постановка проблеми. Досвід локальних війн і збройних конфліктів сучасності показує, що основною відмінністю їх від усіх попередніх, в першу чергу, $\epsilon$ значне зростання обсягів застосування автоматизованих систем управління (АСУ) військами та зброєю для досягненні мети. Саме інформаційна складова військових конфліктів є найбільш динамічним і значущим чинником, який змінює форми, способи i принципи бойового застосування військ (сил), підходи до оцінювання ситуацій i ухвалення рішень, що дозволяє скоротити цикл управління військами і підвищити ефективність їх застосування при використанні перспективних методів обробки даних під час планування та організації матеріально-технічного забезпечення (МТ3) військ (сил) [1].

Керівний склад (особи, що приймають рішення (ОПР)) органів військового управління при управлінні силами і засобами вирішують значну кількість задач управління. Серед усієї сукупності задач управління окремо визначені задачі управління МТЗ військових частин ЗРВ. Для вирішення цих задач необхідне виконання комплексу заходів 3 технічного діагностування радіоелектронних систем зразків зенітного ракетного озброєння [2]. Складність обробки отриманих даних пов'язана з їх великим об'ємом, наявністю кількісних i якісних даних, що характеризуються різними видами невизначеності [2]. Наявність нелінійного характеру залежності вхідних і вихідних даних вимагають використання складного математичного апарату для отримання обгрунтованих оцінок стану зразків зенітного ракетного озброєння при прийнятті рішень.

Для ефективного вирішення цих задач перспективним є використання АСУ. При цьому існуючі АСУ мають обмеження за типами задач, що вирішуються, типами даних, обсягами інформації, що може бути оброблена ними в обмежені проміжки часу [3].

Необхідність вирішення задач планування МТ3 на підставі результатів оцінки та прогнозування технічних показників експлуатаційних властивостей радіоелектронних систем зенітного ракетного озброєння потребує використання інтелектуальних методів обробки даних та вирішення задач прогнозування [2]. Крім того, для реалізації заходів МТЗ в сучасних умовах ведення збройної боротьби особливого значення набуває своєчасне отримання коректних прогнозів щодо технічного стану зразків ОВТ. Виважені прогнози пошкоджень зразків ОВТ ЗРВ дозволятимуть оцінювати обсяг заходів щодо відновлення їх бойової готовності.

Таким чином, наведені обставини висувають підвищені вимоги до способів обробки, зберігання та маніпулювання знаннями та даними в АСУ, а задача розробки методичних підходів щодо отримання прогнозів пошкоджень зразків ОВТ ЗРВ внаслідок застосування противником широкого спектру засобів ураження 3 метою удосконалення інформаційного забезпечення $\epsilon$ актуальною. 
Аналіз літератури. Аналіз літератури [4-8] свідчить, що основна увага авторів приділяється питанню оцінки ефективності дій підрозділів ЗРВ. Зокрема, в [4] наведена методика визначення ймовірностей бойових пошкоджень зразків ОВТ ЗРВ в умовах використання противником як ядерної, так і звичайної зброї. В основу даної методики покладено аналітичну модель процесу пошкодження зразків ОВТ ЗРВ боєприпасами повітряного противника, яка побудована 3 використанням координатного закону ураження зразка ОВТ, коли випадкові точки падіння боєприпасів задаються у відносних координатах i після підриву кожного з боєприпасів визначаються ймовірності можливих станів об'єктів. При цьому процес поразки вважається таким, що розвивається стрибкоподібно в послідовні моменти часу влучення боєприпасів в ціль, тобто так, як він природньо і спостерігається.

В роботі [5] представлена методика визначення очікуваного складу пошкоджених комплектуючих деталей апаратури та обладнання радіолокаційних засобів від дії авіаційних бомб та керованих ракет осколково-фугасного типу. В основі методики покладено імітаційну модель процесу нанесення бойових пошкоджень апаратурі зразка ОВТ ЗРВ. Оцінка ймовірності бойового пошкодження складових частин зразка ОВТ в [5] не проводиться.

Таким чином, проведений аналіз показав, що пошкодження прогнозуються окремо від завдань ï подальшого усунення, зразок ОВТ ЗРВ розглядається як цілісний об'єкт 3 деякою опосередкованою вразливістю, в якості засобів ураження, як правило, розглядаються авіаційні засоби ураження.

Метою статті є удосконалення інформаційного забезпечення перспективної автоматизованої системи управління МТЗ шляхом формування процедури прогнозування очікуваних пошкоджень зразків ОВТ ЗРВ від впливу фугасної дії засобів ураження.

\section{Виклад основного матеріалу дослідження}

Досвід застосування військ (сил) в локальних війнах та збройних конфліктах сучасності свідчить про значну роль засобів повітряного нападу в досягненні визначної мети операції. Під час ведення бойових дій внаслідок застосуванням противником широкого спектру засобів ураження різного типу (протирадіолокаційних ракет, керованих і некерованих реактивних снарядів та авіабомб, крилатих ракет тощо) як по зразку ОВТ ЗРВ, так і по об'єктах, що прикриваються, зразок ОВТ ЗРВ може одержувати пошкодження різного ступеню.

Вплив засобу ураження на зразок ОВТ ЗРВ визначається способом його бойового застосування, конструкцією засобу ураження, характеристиками, які визначають руйнівну дію, та, в залежності від можливостей і термінів відновлення ОВТ силами і засобами ремонтновідновлювальних органів, призводить до різних ступенів пошкоджень ОВТ.

Вплив існуючих i перспективних засобів ураження за характером руйнівної дії розподіляється на ударну, фугасну та осколкову дію. Інші виді впливу за характером руйнівної дії (наприклад кумулятивна) можуть бути зведені до трьох наведених [7].

Засоби ураження за способом нанесення ударів по позиціях підрозділів ЗРВ та по об'єктах, що прикриваються, поділяються на засоби прицільного та площинного ураження.

До засобів прицільного ураження відносяться протирадіолокаційні ракети, керовані і некеровані реактивні снаряди, крилаті ракети, одиночні авіабомби, оперативно-тактичні ракети. Особливістю застосування таких засобів ураження є те, що використовується деяка точка прицілювання, яка може співпадати з зразком ОВТ ЗРB.

В якості основної характеристики для оцінки фугасної дії використовується величина питомого імпульсу вибуху засобу ураження, який дорівнює енергії ударної хвилі вибуху, що впливає (діє) на одиницю площі поверхні структурного елементу засобу ЗРК. Величина питомого імпульсу характеризується дією засобу ураження і пов'язана 3 радіусом пошкодження ОВТ ударною хвилею, приведеною вагою вибухової речовини, тощо.

Імовірність отримання пошкоджень різних ступенів (повного руйнування, сильних, середніх та слабких пошкоджень відповідно) структурного елементу зразка ОВТ ЗРВ від фугасної дії засобів ураження даного типу визначається в припущенні нормального закону розподілу розсіювання засобів прицільного ураження.

Для оцінки фугасної дії в якості основної характеристики використовується величина питомого імпульсу вибуху засобу ураження, який дорівнює енергії ударної хвилі вибуху, що впливає (діє) на одиницю площі поверхні структурного елементу зразка ОВТ ЗРВ [9].

Величина питомого імпульсу $\mathrm{I}_{\mathrm{yx}}$ характеризується дією засобу ураження і пов'язана 3 радіусом пошкодження ОВТ ударною хвилею через наступну залежність:

$$
\mathrm{R}_{\mathrm{yx}}=\frac{\left(1-\mathrm{K}_{\text {осл.фд }}\right) \mathrm{B} \sqrt[3]{\mathrm{G}_{\mathrm{вр. \Pi}}^{2}}}{\mathrm{I}_{\mathrm{yx}}},
$$

де $\mathrm{R}_{\mathrm{yx}}$ - радіус пошкодження структурного елементу зразка ОВТ ЗРВ ударною хвилею;

$\mathrm{I}_{\mathrm{yx}}$ - питомий імпульс, що впливає на структурний елемент зразка ОВТ ЗРВ на відстані $\mathrm{R}_{\mathrm{yx}}$ від точки вибуху засобу ураження;

$\mathrm{B}$ - постійний коефіцієнт, який при спорядженні засобу ураження тротилом, гексогеном та іншими сумішами дорівнює 80;

$\mathrm{G}_{\text {вр.п }}$ - приведена вага вибухової речовини.

Приведена вага вибухової речовини засобу ураження визначається за формулою: 


$$
\mathrm{G}_{\text {вр.п }}=\mathrm{G}_{\text {вр }}\left[1-\frac{\mathrm{V}_{\mathrm{вp}}^{2}\left(1-\alpha_{\text {вр }}\right)}{2 \mathrm{E}_{\text {вр }} \alpha_{\text {вр }}}\right],
$$

де $\mathrm{V}_{\text {вр }}$ - швидкість руху часток вибухової речовини засобу ураження, в тому числі й утворюваних газів;

$\alpha_{\text {вр }}$ - коефіцієнт заповнення об’єму засобу ураження вибуховою речовиною (як правило для авіабомб-0,5, для ракетних снарядів-0,7, для артилерійських снарядів та мін $-0,1 \ldots 0,2)$;

$\mathrm{E}_{\text {вр }}$ - енергія вибуху вибухової речовини засобу ураження.

Енергія вибуху вибухової речовини визначається за формулою:

$$
\mathrm{E}_{\text {вр }}=427 \mathrm{gQ},
$$

де Q - теплотворна здатність 1 кг вибухової речовини (для тротилу $-1000 \ldots 1100$ (ккал/кг), для гексогену і сумішей типу ТГА - $1200 \ldots 1300$ (ккал/кг);

$\mathrm{g}=9,81(\mathrm{~m} / \mathrm{c} 2)-$ прискорення сили земного тяжіння;

Швидкість руху часток вибухової речовини визначається за формулою:

$$
\mathrm{V}_{\text {вр }}=\frac{\mathrm{V}_{\text {д }}}{2} \sqrt{\frac{\alpha_{\text {вр }}}{2-\alpha_{\text {вр }}}},
$$

де $\mathrm{V}_{\text {д }}$ - швидкість детонації вибухової речовини (для тротилу $-7000 \mathrm{~m} / \mathrm{c}$, для гексогену і сумішей типу ТГА $-8000 \mathrm{~m} / \mathrm{c}$ ).

Вплив фугасної дії засобів прицільного ураження зменшується за рахунок інженерного обладнання позицій. Величина зменшення цього впливу характеризуються коефіцієнтом ослаблення фугасної дії $\mathrm{K}_{\text {осл.фд, який }}$ розраховується за формулою:

$$
\mathrm{K}_{\text {осл.фд }}= \begin{cases}\mathrm{K}_{\text {зах }}, & \text { якщо } \mathrm{L}_{\text {зах }} \geq \mathrm{L}_{\text {руйн.фд }} ; \\ \frac{\mathrm{K}_{\text {зах }} \mathrm{L}_{\text {зах }}}{\mathrm{L}_{\text {руйн.фд }}}, & \text { якщо } \mathrm{L}_{\text {зах }}<\mathrm{L}_{\text {руйн.фд }},\end{cases}
$$

де $\mathrm{L}_{\text {руйн.фд }}$ - глибина руйнування захисної перешкоди засобом ураження, яка розраховується за формулою:

$$
\begin{aligned}
& \mathrm{L}_{\text {руйн.фд }}=\mathrm{K}_{\text {руйн }} \sqrt[3]{\mathrm{G}_{\text {вр }}},(6) \\
& \mathrm{P}_{\text {ф.сп }}\left(\mathrm{K}, \mathrm{R}_{\phi . с п}\right)=\exp \left[-\rho^{2}\left(\frac{\mathrm{R}_{\phi . п р}}{\mathrm{E}}\right)^{2} \mathrm{~K}\right]-\exp \left[-\rho^{2}\left(\frac{\mathrm{R}_{\phi . с п}}{\mathrm{E}}\right)^{2} \mathrm{~K}\right],
\end{aligned}
$$

де $\mathrm{R}_{\text {ф.п }}-$ радіус зони сильних пошкоджень структурного елементу зразка ОВТ ЗРВ ударною хвилею, який, в свою чергу, визначається за формулою:

$$
\begin{aligned}
& \mathrm{R}_{\text {ф.сп }}=\mathrm{R}_{\text {ф.пр }}+\mathrm{R}_{\text {yх.сп }} . \\
& \mathrm{P}_{\text {фд.серп }}\left(\mathrm{K}, \mathrm{R}_{\text {ф.серп }}\right)=\exp \left[-\rho^{2}\left(\frac{\mathrm{R}_{\text {ф.сп }}}{\mathrm{E}}\right)^{2} \mathrm{~K}\right]-\exp \left[-\rho^{2}\left(\frac{\mathrm{R}_{\text {ф.серп }}}{\mathrm{E}}\right)^{2} \mathrm{~K}\right] \text {, }
\end{aligned}
$$

де $\mathrm{G}_{\text {вр }}$ - фактична вага вибухової речовини в засобі ураження;

$\mathrm{K}_{\text {руйн }}$ - коефіцієнт податливості матеріалу захисної споруди.

Після підставляння величин питомого імпульсу для різних ступенів пошкоджень у співвідношення (1) отримуються відповідні величини радіусів пошкоджень зразків $\mathrm{OBT} \quad \mathrm{R}_{\mathrm{yx} . п р}, \mathrm{R}_{\mathrm{yx.сп}}$, $\mathrm{R}_{\text {ух.серп }}, \mathrm{R}_{\text {ух.слп }}$ ударною хвилею:

$$
\begin{aligned}
& \mathrm{R}_{\text {ух.пр }}=\frac{\left(1-\mathrm{K}_{\text {осл.фд }}\right) \mathrm{B} \sqrt[3]{\mathrm{G}_{\text {вр.п }}^{2}}}{\mathrm{I}_{\text {ух.пр }}} . \\
& \mathrm{R}_{\mathrm{yx} . с п}=\frac{\left(1-\mathrm{K}_{\text {осл.фд }}\right) \mathrm{B} \sqrt[3]{\mathrm{G}_{\mathrm{вp.п}}^{2}}}{\mathrm{I}_{\mathrm{yx} . с п}} .
\end{aligned}
$$

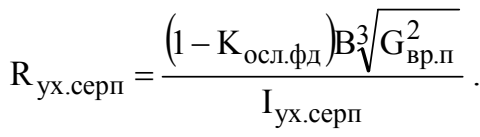

$$
\begin{aligned}
& \mathrm{R}_{\text {ух.слп }}=\frac{\left(1-\mathrm{K}_{\text {осл.фд }}\right) \mathrm{B} \sqrt[3]{\mathrm{G}_{\text {вр.п }}^{2}}}{\mathrm{I}_{\text {ух.слп }}} .
\end{aligned}
$$

Ймовірність повного руйнування структурного елементу зразка ОВТ ЗРВ від фугасної дії $\mathrm{P}_{\text {фд.пр }}\left(\mathrm{K}, \mathrm{R}_{\phi . п р}\right)$ засобів ураження даного типу в кількості К визначається за формулою:

$$
\mathrm{P}_{\text {фд.пр }}\left(\mathrm{K}, \mathrm{R}_{\text {ф.пр }}\right)=1-\exp \left[-\rho^{2}\left(\frac{\mathrm{R}_{\text {ф.пр }}}{\mathrm{E}}\right)^{2} \mathrm{~K}\right],
$$

де $\mathrm{R}_{\text {ф.пр }}$ - радіус зони повного руйнування структурного елементу зразка ОВТ ЗРВ ударною хвилею, який, в свою чергу, визначається за формулою:

$$
\mathrm{R}_{\text {ф.пр }}=\mathrm{R}_{\text {п }}+\mathrm{R}_{\mathrm{yx} . п р} \text {. }
$$

Ймовірність отримання сильних пошкоджень структурного елементу зразка ОВТ ЗРВ від фугасної дії $\mathrm{P}_{\text {фд.сп }}\left(\mathrm{K}, \mathrm{R}_{\text {ф.пп }}\right)$ засобів ураження даного типу в кількості $\mathrm{K}$ визначається за формулою:
Ймовірність отримання середніх пошкоджень структурного елементу зразка ОВТ ЗРВ від фугасної дії $\mathrm{P}_{\text {ф.серп }}\left(\mathrm{K}, \mathrm{R}_{\text {ф.серп }}\right)$ засобів ураження даного типу в кількості К визначається за

де $\mathrm{R}_{\text {фсерп }}$ - радіус зони середніх пошкоджень хвилею, який, в свою чергу, визначається за формулою: 


$$
\mathrm{R}_{\text {ф.серп }}=\mathrm{R}_{\text {ф.сп }}+\mathrm{R}_{\text {ух.серп }}
$$

Ймовірність отримання слабких пошкоджень структурного елементу зразка ОВТ ЗРВ від фугасної дії $\mathrm{P}_{\text {фд.слп }}\left(\mathrm{K}, \mathrm{R}_{\text {ф.слп }}\right)$ засобів ураження даного типу в кількості К визначається за формулою:

$$
\mathrm{P}_{\text {фд.слп }}\left(\mathrm{K}, \mathrm{R}_{\text {ф.слп }}\right)=\exp \left[-\rho^{2}\left(\frac{\mathrm{R}_{\text {ф.серп }}}{\mathrm{E}}\right)^{2} \mathrm{~K}\right]-\exp \left[-\rho^{2}\left(\frac{\mathrm{R}_{\text {ф.слп }}}{\mathrm{E}}\right)^{2} \mathrm{~K}\right] \text {, }
$$

де $\mathrm{R}_{\text {ф.лп }}-$ радіус зони слабких пошкоджень структурного елементу зразка ОВТ ЗРВ ударною хвилею, який, в свою чергу, визначається за формулою:

$$
\mathrm{R}_{\text {ф.слп }}=\mathrm{R}_{\text {ф.серп }}+\mathrm{R}_{\text {ух.слп }} .
$$

До засобів площинного ураження відносяться авіабомби при серійному бомбометанні, авіаційні та ракетно-артилерійські засоби ураження 3 касетними бойовими частинами, засоби ураження реактивних систем залпового вогню, артилерійські снаряди та міни. Особливістю застосування цих засобів ураження $є$ те, що вони використовуються для нанесення ураження по площам, всередині яких можуть знаходитися зразки ОВТ ЗРВ.

Основною характеристикою для оцінки фугасної дії засобів площинного ураження так само, як і для засобів прицільного ураження, $€$ величина питомого імпульсу вибуху засобу ураження. Вплив фугасної дії засобів площинного ураження зменшується за рахунок інженерного обладнання позицій. Величина зменшення цього впливу характеризуються коефіцієнтом ослаблення фугасної дії $\mathrm{K}_{\text {осл.фд, порядок }}$ розрахунку якого аналогічний наведеному для засобів прицільного ураження.

Величини питомого імпульсу вибуху, порядок розрахунків приведеної ваги вибухової речовини засобу ураження, енергії вибуху вибухової речовини, швидкості руху часток вибухової речовини та радіусів пошкоджень ОВТ $\mathrm{R}_{\mathrm{yx.пр}}$, $\mathrm{R}_{\text {ух.сп }}, \quad \mathrm{R}_{\text {ух.серп }}, \quad \mathrm{R}_{\text {ух.слп }}$ ударною хвилею аналогічні наведеним вище для засобів прицільного ураження (співвідношення 7 - 10).

$$
\mathrm{P}_{\text {фд.серп }}^{\text {пл }}\left(\mathrm{K}, \mathrm{R}_{\text {ф.серп }}\right)=\left(1-\frac{\pi \mathrm{R}_{\text {ф.сп }}^{2}}{\mathrm{~S}_{\text {роз }}}\right)^{\mathrm{K}}-\left(1-\frac{\pi \mathrm{R}_{\text {ф.серп }}^{2}}{\mathrm{~S}_{\text {ро3 }}}\right)^{\mathrm{K}} .
$$

Радіус зони середніх пошкоджень $\mathrm{R}_{\text {ф.серп }}$ структурного елементу зразка ОВТ ЗРВ ударною хвилею визначається за формулою (16).

Ймовірність отримання слабких пошкоджень структурного елементу зразка ОВТ ЗРВ від фугасної дії $\quad \mathrm{P}_{\text {фд.слп }}\left(\mathrm{K}, \mathrm{R}_{\text {ф.слп }}\right)$ засобів

$$
\mathrm{P}_{\text {фд.слп }}^{\text {Пл }}\left(\mathrm{K}, \mathrm{R}_{\text {ф.слл }}\right)=\left(1-\frac{\pi \mathrm{R}_{\text {ф.серп }}^{2}}{\mathrm{~S}_{\text {роз }}}\right)^{\mathrm{K}}-\left(1-\frac{\pi \mathrm{R}_{\text {ф.слп }}^{2}}{\mathrm{~S}_{\text {роз }}}\right)^{\mathrm{K}} .
$$

Запропонований підхід до прогнозування пошкоджень зразків ОВТ ЗРВ від впливу фугасної площинного ураження даного типу в кількості К визначається за формулою (22).

Радіус зони слабких пошкоджень $\mathrm{R}_{\text {ф.сп }}$ структурного елементу зразка ОВТ ЗРВ ударною хвилею визначається за формулою (18).

дії засобів ураження в подальшому планується до реалізації у вигляді інформаційно-розрахункових 
задач в АCУ, практичне застосування якої спрямоване на забезпечення необхідної оперативності прийняття рішень ОПР; інтеграцію структур, які забезпечують формалізацію логікоаналітичних задач із процедурами вирішення інформаційно-розрахункових задач, що дозволить досягти необхідного рівня обгрунтованості прийнятих рішень.

Висновки Таким чином, в результаті розробки методичних підходів щодо отримання прогнозів пошкоджень зразків ОВТ ЗРВ внаслідок фугасної дії засобів ураження противника, а також уточнення результатів прогнозування втрат (ступенів пошкоджень) зразків ОВТ ЗРВ, з метою

\section{Лimepamypa}

1. Ярош С.П. Теоретичні основи побудови та застосуваннярозвідувально-управляючих інформаційних систем протиповітряної оборони: монографія / С. П. Ярош; за ред. І. О. Кириченка. - Х.: ХУПС, 2012. - 512 c. 2. Опенько П.В. Перспективи розвитку системи технічного забезпечення зенітних ракетних військ / П. В. Опенько, А. В. Крижний, П. А. Дранник // Проблеми створення, випробування, застосування та експлуатації складних інформаційних систем. - 2015. - Вип. 10. - С. 148-157. 3. Інтелектуальні системи підтримки прийняття рішень:теорія, синтез, ефективність / В.О. Тарасов, Б.М. Герасимов, І.О. Левін, В.О. Корнійчук. К.: МАКНС, 2007. - 336 с. 4. Гребенников Н.Д. Восстановление вооружения и боевой техники ЗРВ ПВО страны. / Н. Д. Гребенников. - Минск: МВИЗРУ, 1972. 240 с. 5. Ковтуненко А.П. Восстановление эксплуатационных свойств радиоэлектронных систем / удосконалення інформаційного забезпечення АСУ МТ3 проведений розрахунок імовірності отримання пошкоджень для прицільного i площинного способів ураження 3 урахуванням інженерного обладнання позиції зразка озброєння.

Реалізація запропонованого підходу у вигляді інформаційно-розрахункових задач в АСУ дозволить ОПР в органах управління МТЗ ЗРВ отримувати коректні результати розрахунків щодо очікуваних втрат ОВТ ЗРВ внаслідок застосуванням противником засобів ураження ударної дії 3 характеристикою ступеню пошкоджень складових зразків ОВТ.

Ковтуненко А.П., Козлов В.Н., Россинский Ю.М. - М.: МО, 1980. - 257 с. 6. Ковтуненко А.П. Основы теории восстановления эксплуатационных свойств технических систем : монография / А.П. Ковтуненко, М.А. Шишанов, В.В. Зубарев. - К.: Книжкове видавництво НАУ, 2007. 301 с. 7. Петухов С.И. Эффективность ракетных средств ПВО. / С.И. Петухов, А.Н. Степанов. - М.: Воениздат, 1976. - 73 с. 8. Кириченко В.Д. Совершенствования системы восстановления вооружения и военной техники войскового ПВО с учетом особенностей боевых действий / В. Д. Кириченко, А. Г. Лузан, А. Г. Малахов // Военная радиоэлектроника. - 1986. - №. 5(440). - С. 160-167. 9. Физика взрыва: в 2 т. / [С.Г. Андреев, А.В. Бабкин, Ф.А. Баум и др.]; под ред. Л.П. Орленко. М.: Физматлит, 2002.-.- Т.1. -2002.- 832 c.

\title{
ФОРМАЛИЗАЦИЯ ПРОЦЕДУРЫ ПРОГНОЗИРОВАНИЯ ПОВРЕЖДЕНИЙ ВООРУЖЕНИЯ И ВОЕННОЙ ТЕХНИКИ ЗЕНИТНЫХ РАКЕТНЫХ ВОЙСК В ПЕРСПЕКТИВНЫХ АВТОМАТИЗИРОВАННЫХ СИСТЕМАХ УПРАВЛЕНИЯ МАТЕРИАЛЬНО-ТЕХНИЧЕСКИМ ОБЕСПЕЧЕНИЕМ
}

\author{
${ }^{1}$ Денис Михайлович Запара \\ ${ }^{1}$ Михаил Борисович Бровко \\ ${ }^{1}$ Сергей Анатольевич Бортновский (канд. техн. наук, доцент) \\ ${ }^{2}$ Павел Викторович Опенько (канд. техн. наук)
}

${ }^{1}$ Харковський национальный университет Воздуиных Сил имени Ивана Кожедуба, Харьков, Украина

${ }^{2}$ Национальный университет обороны Украины имени Ивана Черняховского, Киев, Украина

В статье рассматриваются вопросы совершенствования информаџионного обеспечения перспективной автоматизированной системь управления материально-техническим обеспечением путем формирования процедуры прогнозирования ожидаемых повреждений образиов вооружения и военной техники (BВT) зенитных ракетных войск (ЗРВ) непосредственно от воздействия фугасного действия средства поражения. Качественным показателем прогнозирования уровня повреждений образиа ВВТ ЗРВ выбран признак степени его повреждений, в качестве критерия определения степени повреждений образиа ВВТ ЗРВ от воздействия фугасного действия средств поражения выбрано количество средств поражения, которые поразили. Проведен расчет вероятности получения повреждений структурным элементом образиа ВВТ ЗРВ от фугасного действия средств поражения с учетом инженерного оборудования позиций.

Ключевые слова: материально-техническое обеспечение, средства поражения, образеи вооружения и военной техники, повреждения, структурный элемент, фугасное действие, площадное поражение, прицельное поражение.

\section{FORMALIZATION OF THE FORECASTING PROCEDURE FOR DAMAGE TO ARMAMENT AND MILITARY EQUIPMENT OF AIR DEFENCE TROOPS IN PERSPECTIVE LOGISTIC SUPPORT AUTOMATIC CONTROL SYSTEM}

\author{
${ }^{1}$ Denys M. Zapara \\ ${ }^{1}$ Mykhailo B. Brovko \\ ${ }^{1}$ Serhii A. Bortnovskyi (PhD, Associate Professor)
}




\section{${ }^{2}$ Pavlo V. Openko (PhD) \\ ${ }^{1}$ Ivan Kozhedub Kharkiv National University of Air Force \\ ${ }^{2}$ National Defence University of Ukraine named after Ivan Cherniakhovsky, Kyiv, Ukraine}

The article deals with the issues of improving the information support of a perspective logistic support automatic control system by forming the procedure for predicting the expected damage to armament and military equipment (AME) of air defence troops (ADT) directly from the impact of the explosive action of the weapon.

The main attention is paid to the issue of assessing the effectiveness of the actions of the ADT units. Damages are provided separately from the tasks of their further elimination, the AME model is considered as an integral object. As a means of destruction, aircraft weapons are mainly considered. In accordance with the criteria of distribution of the results that are expected during one type of strike, all samples of AME are classified into groups.

A qualitative indicator of the prediction of the level of damages of the AME model of ADT sample is the sign of the degree of its damage.

The criterion for determining the degree of damage to an AME model of ADT specimen from the explosive action of the weapon is the number of AME that have been hit. Calculation of the probability of obtaining the damage by a structural element of any of the armament model of ADT from the explosive action of the weapon was conducted with taking into account the engineering equipment of the positions.

Such an approach allows the control authorities of the logistic support of ADT to receive correct calculation results for the expected losses of AME ADT systems. As a result of fact that the enemy uses weapon an explosive action is a characteristic of the degree of damage.

Keywords: logistic support system, means of destruction, a sample of armament and military equipment, damage, structural element, explosive action, area defeat, sight defeat.

\section{References}

1. Yarosh, S.P. (2012), Theoretical foundations of the construction and application of intelligence-control information systems of air defense [Teoretychni osnovy pobudovy ta zastosuvannya rozviduvalno-upravlyayuchyx informacijnyx system protypovitryanoyi oborony]. Kharkiv, HUPS, 2012. - 512 p. 2. Openko, P.V. (2015), Prospects for the development of the technical support system for anti-aircraft missile troops [Perspektyvy rozvytku systemy tekhnichnogo zabezpechennya zenitnykh raketnykh vijsk] / P.V. Openko, A.V. Kryzhnyj, P.A. Drannyk // Problems of creation, testing, application and operation of complex information systems, Vol. 10. - pp. 148-157. 3. Tarasov, V.O., Gerasymov, B.M., Levin, I.O., Kornijchuk, V.O. (2007), Intelligent decision support systems: theory, synthesis, and effectiveness [Intelektualni systemy pidtrymky pryjnyattya rishen: teoriya, syntez, efektyvnist]. Kyiv, MAKNS, 2007. - 336 p. 4. Hrebennykov, N.D., (1972), Restoration of armament and military equipment of anti-aircraft missile troops of Air Defense Forces of the country [Vosstanovlenye vooruzhenyia y boevoi tekhnyky ZRV PVO strany]. - Mynsk, MVYZRU, 1972. - 240 p. 5. Kovtunenko, A.P., Kozlov, V.N., Rossinskiy, Yu.M.
(1980), Restoring the operational properties of radio electronic systems [Vosstanovlenie ekspluatatsionnyih svoystv radioelektronnyih sistem]. - Moskva, MD, 1980. 257 p. 6. Kovtunenko, A.P., Shishanov, M.A., Zubarev, V.V. (2007), Fundamentals of the theory of restoration of operational properties of technical systems [Osnovyi teorii vosstanovleniya ekspluatatsionnyih svoystv tehnicheskih sistem]. - Kyiv, NAU, 2007. - 301 p. 7. Petukhov, S.Y., Stepanov, A.N., (1976), Efficiency of missile air defense systems [Jeffektivnost raketnyh sredstv PVO]. - Moskva, Military Publishing, 1976. - 73 p. 8. Kirichenko, V. D. (1986), Improvement of the system for the restoration of armament and military equipment of Army antiaircraft defense into account the characteristics of combat operations [Sovershenstvovaniya sistemyi vosstanovleniya vooruzheniya $\mathrm{i}$ voennoy tehniki voyskovogo PVO $\mathrm{s}$ uchetom osobennostey boevyih deystviy] / V. D. Kirichenko, A. G. Luzan, A. G. Malahov // Military electronics, Vol. 5(440). - pp. 160-167. 9. Andreev, S.G., Babkin, A.V., Baum, F.A. (2002), Physics of the explosion [Fizika vzryiva]. - Moskva, Fizmatlit, 2002. - 832 p. 